Article

\title{
High-Throughput Sequencing Reveals Further Diversity of Little Cherry Virus 1 with Implications for Diagnostics
}

\author{
Asimina Katsiani ${ }^{1}$, Varvara I. Maliogka ${ }^{1, * \mathbb{B}}$, Nikolaos Katis ${ }^{1}$, Laurence Svanella-Dumas ${ }^{2}$, \\ Antonio Olmos ${ }^{3}$ (1) , Ana B. Ruiz-García ${ }^{3}$, Armelle Marais ${ }^{2}{ }^{(1)}$, Chantal Faure ${ }^{2}$, Sébastien Theil ${ }^{2}$, \\ Leonidas Lotos ${ }^{1}$ (D) and Thierry Candresse ${ }^{2}$ (D) \\ 1 Laboratory of Plant Pathology, School of Agriculture, Faculty of Agriculture, Forestry and Natural \\ Environment, Aristotle University of Thessaloniki, 54124 Thessaloniki, Greece; akatsian@uark.edu (A.K.); \\ katis@agro.auth.gr (N.K.); llotos@agro.auth.gr (L.L.) \\ 2 UMR 1332 Biologie du Fruit et Pathologie, INRA, University of Bordeaux, CS20032, Villenave d'Ornon \\ CEDEX, F-33882 Bordeaux, France; laurence.svanella-dumas@inra.fr (L.S.-D.); \\ armelle.marais-colombel@inra.fr (A.M.); chantal.faure@inra.fr (C.F.); sebastien.theil@inra.fr (S.T.); \\ thierry.candresse@inra.fr (T.C.) \\ 3 Centro de Protección Vegetal y Biotecnología, Instituto Valenciano de Investigaciones Agrarias (IVIA), Ctra. \\ Moncada-Naquera km 4.5, Moncada, 46113 Valencia, Spain; aolmos@ivia.es (A.O.); \\ ana.belen.ruiz@uv.es (A.B.R.-G.) \\ * Correspondence: vmaliogk@agro.auth.gr; Tel.:+30-2310-998716
}

Received: 23 May 2018; Accepted: 19 July 2018; Published: 21 July 2018

\begin{abstract}
Little cherry virus 1 (LChV1, Velarivirus, Closteroviridae) is a widespread pathogen of sweet or sour cherry and other Prunus species, which exhibits high genetic diversity and lacks a putative efficient transmission vector. Thus far, four distinct phylogenetic clusters of LChV1 have been described, including isolates from different Prunus species. The recent application of high throughput sequencing (HTS) technologies in fruit tree virology has facilitated the acquisition of new viral genomes and the study of virus diversity. In the present work, several new LChV1 isolates from different countries were fully sequenced using different HTS approaches. Our results reveal the presence of further genetic diversity within the LChV1 species. Interestingly, mixed infections of the same sweet cherry tree with different LChV1 variants were identified for the first time. Taken together, the high intra-host and intra-species diversities of LChV1 might affect its pathogenicity and have clear implications for its accurate diagnostics.
\end{abstract}

Keywords: LChV1; Closteroviridae; intra-host variability; high-throughput sequencing; diagnostics

\section{Introduction}

Little cherry virus 1 (LChV1), a member of the genus Velarivirus (family Closteroviridae), is a graft-transmissible pathogen and its host range includes mainly sweet or sour cherry and other Prunus species [1]. Besides the typical reddening frequently observed in cherry leaves, some LChV1 isolates have been associated with various plant disorders [2,3]. LChV1 has a long, positive-sense, single-stranded RNA genome, which encodes eight open reading frames (ORFs) [4]. ORF 1a and ORF $1 b$, with ORF $1 b$ expressed by a frameshift of ORF 1a, encode a large protein with papain-like proteinase (P-PRO), methyltransferase (MET) and Helicase (HEL) domains and a protein containing an RNA-dependent RNA polymerase (RdRp) conserved domain, respectively. ORF 2 encodes a small hydrophobic protein $(4 \mathrm{kDa})$ which partially overlaps with the ORF 3 that encodes a $70 \mathrm{kDa}$ heat-shock protein 70 homolog (HSP70h). ORF 4 encodes a polypeptide of $61 \mathrm{kDa}$ and partially 
overlaps with ORF 3, ORF 5 and ORF 6 encode the coat protein $(\mathrm{CP})$ and the CP minor (CPm), respectively, whereas ORF 7 and ORF 8 encode polypeptides of respectively 21 and $27 \mathrm{kDa}$, with currently unknown functions.

LChV1 exhibits high genetic diversity as revealed from partial or full genome sequencing of various isolates. So far, the complete genome of several LChV1 isolates has been determined [2-7]. The UW2 and ITMAR isolates are highly similar, whereas isolate V2356 differs significantly from them and represents the first fully sequenced one of a second phylogenetic group which also includes isolates from the US [2,3]. A third group is formed with the isolates Jerte, Ponferrada, Taian and YD [5-7]. Phylogenetic analyses using partial sequences of the RdRp, the HSP70h and the CP have classified LChV1 isolates into 4 clusters, including the three above mentioned ones [8]. Even though the intragroup diversity appears to be relatively low (3.3\% to $7.4 \%$ in nts), the genetic distances between the different phylogenetic groups are higher (15\% to $39 \%$ in nts) [3,5-8].

High throughput sequencing (HTS) has been used in plant virology since $2009[9,10]$. HTS provides highly efficient, rapid and cost-effective sequencing of the genomes of plant viruses and viroids [11]. Different approaches, such as sequencing of total RNA, double-stranded RNA (dsRNA) or small RNAs (sRNAs) have been developed. HTS was used in a number of studies in plant virology including, but not limited to, discovery of novel viruses and viroids as well as analysis of genome diversity and evolution, and study of pathogen epidemiology and population structure [12-14]. Another area where HTS has proven very valuable is in the detection of divergent variants of known viruses that escape existing detection procedures, particularly PCR or RT-PCR assays [15]. Because of its unbiased nature, the data obtained by HTS may provide a better knowledge of the polyvalence or specificity of existing assays and, if needed, facilitate the design of new detection primers of broader specificity, thus contributing to the improvement of classical detection methods.

In the present study, seven novel LChV1 isolates were fully sequenced using HTS technologies. One of the isolates (G153) was recently partially characterized and shown to exhibit the highest genetic divergence from all so far known isolates [8]. The sequences of the other LChV1 isolates described herein were acquired during HTS analysis of several sweet or flowering cherry samples from three different countries. Our results highlight the presence of further genetic diversity in the populations of LChV1, with clear implications for the diagnosis of this viral agent of quarantine status or included in cherry certification in a number of countries.

\section{Materials and Methods}

\subsection{Full Genome Sequencing of LChV-1 Isolates Using HTS Approaches}

Three sweet cherry and one flowering cherry samples from Greece (G15 3, C118), Spain (P8) and Japan (Kyoto-2) were analyzed using different HTS approaches (Table 1). The G15 3 isolate (LN794218) was obtained from a sweet cherry tree (cv. Tragana Edessis) which did not show any virus-like symptoms. The sample was collected in 2009 from a Greek stone fruit orchard (Aridaia Pella) and a part of the isolate's sequence was previously determined, showing high divergence from other known LChV1 isolates [8]. The Kyoto-2 isolate (MG934545) was obtained from a flowering cherry (Prunus serrulata) with conspicuous yellowish oak-leaf pattern symptoms collected in late spring 2015 in the Kyoto prefecture of Japan. The C118-Iso1 (MH364114), C118-Iso13 (MH364115) and C118-Iso15 (MH364116) isolates were obtained from C118, a sweet cherry tree (cv. Larian) showing no obvious symptoms, collected in summer 2014 from a Greek nursery in Rizari (Pella) and maintained in the premises of the Laboratory of Plant Pathology until sequenced in 2017. The P8-23 (MH300060) and P8-42 (MH300061) isolates were obtained from P8, a sweet cherry tree (cv. Planera) showing reddening of the leaves collected in early summer 2017 in Alicante, Spain. 
Table 1. Description of analyzed samples and viral species identified with high throughput sequencing (HTS).

\begin{tabular}{|c|c|c|c|c|c|c|c|c|c|c|c|c|c|}
\hline \multirow{2}{*}{ Sample ID } & \multirow{2}{*}{ Plant Species } & \multirow{2}{*}{ Country } & \multirow{2}{*}{ Symptoms } & \multirow{2}{*}{ HTS Template } & \multirow[b]{2}{*}{ APCLSV } & \multicolumn{8}{|c|}{ Viruses Present } \\
\hline & & & & & & $\mathrm{CVF}$ & PDV & LChV1 & LChV2 & CVA & PBNSPaV & CNRMV & APLPV \\
\hline G15 3 & $\begin{array}{l}\text { Prunus avium cv. } \\
\text { Tragana-edessis }\end{array}$ & Greece & no & sRNAs & & + & + & + & & & & & \\
\hline Kyoto-2 & Prunus serrulata & Japan & $\begin{array}{l}\text { yellowish oak-leaf } \\
\text { pattern symptoms }\end{array}$ & dsRNA & & & & + & + & + & + & + & + \\
\hline C118 & $\begin{array}{l}\text { Prunus avium } \\
\text { cv.Larian }\end{array}$ & Greece & no & Total RNA & + & & & $\begin{array}{l}\text { Multiple } \\
\text { genotypes }\end{array}$ & & + & & + & \\
\hline P8 & $\begin{array}{l}\text { Prunus avium } \\
\text { cv.Planera }\end{array}$ & Spain & reddening of leaves & Total RNA & & & + & $\begin{array}{l}\text { Multiple } \\
\text { genotypes }\end{array}$ & & + & & & \\
\hline
\end{tabular}

HTS: High-throughput sequencing, sRNAs: small RNAs, dsRNA: double-stranded RNA, APCLSV: Apricot pseudo-chlorotic leaf spot virus, CVF: Cherry virus F, PDV: Prune dwarf virus,

LChV1: Little cherry virus 1, LChV2: Little cherry virus 2, CVA: Cherry virus A, PBNSPaV: Plum bark necrosis and stem pitting-associated virus, CNRMV: Cherry necrotic rusty mottle virus,

APLPV: American plum line pattern virus. The viral species identified in the samples are indicated with " + ". 
The samples were subjected to total RNA, small RNAs (sRNAs) or double-stranded RNA (dsRNA) extraction before their HTS analysis (Table 1). More specifically sRNAs were isolated from leaf midribs of the G15 3 infected sweet cherry tree using the mirPremier microRNA Isolation Kit (Sigma-Aldrich, St. Louis, MO, USA). Double-stranded RNAs were extracted from P. serrulata symptomatic leaves as previously reported (3) and total RNA was extracted from leaf and petiole tissue of the C118 and P8 samples using the Plant/Fungi total RNA purification kit (NorgenBiotek Corporation, Thorold, ON, Canada) according to the manufacturer's protocol.

cDNA libraries and HTS of G15 3 were performed by LifeSequencing S.L. (Paterna, Spain) on an Ion Torrent platform using the Ion chip 318. Complementary DNA obtained from the purified dsRNAs of Kyoto2 was sequenced in multiplex using the Illumina Miseq platform. Finally, the samples C118 and P8 were subjected to rRNA depletion, library construction and high throughput sequencing (150 bp paired-end reads, total output 20 million) in a NextSeq 500 platform (Illumina, San Diego, CA, USA) at Life Sequencing S.L. (Paterna, Spain). In all cases the obtained reads were de novo assembled using CLC Genomics Workbench v.10.1.1 (Qiagen Bioinformatics, Hilden, Germany). For the total RNA reads prior to de novo assembly the host genome was removed using the same software. In addition, in the case of G15 3 all sRNAs used for the construction of the contigs, were mapped on the V2356, ITMAR and UW2 isolate sequences. The de novo contigs produced were blasted (BLASTn/x) against local and online virus, viroids and $\mathrm{nt} / \mathrm{nr}$ databases.

In order to confirm the G15 3 and Kyoto-2 sequences obtained from HTS data and to fill sequence gaps, primer pairs were designed from contig sequences (Table S1) and used in RT-PCR assays. More specifically, in the case of G15 3, the cDNA was synthesized by adding $5 \mu \mathrm{L}$ of total RNA in the RT mixture [250 mM Tris-HCl (pH 8.3), $375 \mathrm{mM} \mathrm{KCl,} 15 \mathrm{mM} \mathrm{MgCl2,} 0.5 \mathrm{mM}$ of each (dNTP), $0.4 \mu \mathrm{M}$ of random hexameres $5^{\prime} \mathrm{d}(\mathrm{N} 6) 3^{\prime}[\mathrm{N}=\mathrm{A}, \mathrm{C}, \mathrm{G}, \mathrm{T}]$ and 60 units of Superscript ${ }^{\circledR} \mathrm{II}$ (Invitrogen, Gröningen, The Netherlands)] in a total volume of $20 \mu \mathrm{L}$. The reaction was performed under the following profile: $15^{\prime}$ in $18^{\circ} \mathrm{C}, 40^{\prime}$ in $37^{\circ} \mathrm{C}, 15^{\prime}$ in $42^{\circ} \mathrm{C}$ and $5^{\prime}$ in $95^{\circ} \mathrm{C}$. Five $\mu \mathrm{L}$ of the cDNA were added in the PCR mixture containing $10 \mathrm{mM}$ Tris- $\mathrm{HCl}$ (pH 8.8), $50 \mathrm{mM} \mathrm{KCl}, 1.5 \mathrm{mM} \mathrm{MgCl}_{2}, 0.1 \%$ Triton X-100, 5\% DMSO, $0.2 \mathrm{mM}$ of each dNTP and 0.5 units Dynazyme ${ }^{\mathrm{TM}}$ II DNA Polymerase and $0.4 \mu \mathrm{M}$ from each primer (Table S1). The cycling profile consisted of a step at $95^{\circ} \mathrm{C}$ for $5 \mathrm{~min}$, and 40 cycles segmented in $30 \mathrm{~s}$ at $95{ }^{\circ} \mathrm{C}, 30 \mathrm{~s}$ at $55^{\circ} \mathrm{C}$ and $60 \mathrm{~s}$ at $72{ }^{\circ} \mathrm{C}$, followed by one final extension step at $72{ }^{\circ} \mathrm{C}$, for $5 \mathrm{~min}$.

In case of Kyoto-2, complementary DNAs were synthesized from $3 \mu \mathrm{L}$ of purified dsRNAs using N6 and dT18 primers and the Superscript II Reverse Transcriptase (Invitrogen, Gröningen, The Netherlands), according to the manufacturer's recommendations. In a second step, the PCR amplification was carried out using $2 \mu \mathrm{L}$ of cDNA in a $50 \mu \mathrm{L}$ reaction volume, $0.2 \mu \mathrm{M}$ of each specific primer and $1 \mu \mathrm{L}$ of $50 \times$ Advantage 2 Polymerase mix (Clontech, Mountain View, CA, USA) according to the manufacter's recommendations. The $5^{\prime}$ and $3^{\prime}$ genome ends of Kyoto-2 isolate were determined using specific primers (Table S1) designed from terminal contig sequences and Rapid Amplification of cDNA Ends on purified dsRNAs (RACE, Takara Bio Europe/Clontech, Saint-Germain-en-Laye, France). All amplifications products were sequenced by Genewiz (Paris, France).

\subsection{Phylogenetic and Sequence Analysis of LChV1 Isolates}

For the analysis of the sequences determined in this study, all full-length genome sequences available from the EMBL-EBI and GenBank databases, as well as partial sequences included in a recent phylogenetic analysis [8] were used. ORFs were determined with "ORF finder" (http: / / www.bioinformatics.org/sms2/orf_find.html) (Department of Biological Sciences, University of Alberta, Edmonton, Canada) and the identity scores in aminoacids and nucleotides with the GeneDoc software version 2.7.0 (Copyright (C) 2006, Karl Nicholas) [16]. Multiple sequence alignments were performed with Muscle (MUltiple Sequence Comparison by Log-Expectation) [17]. Phylogenetic trees were constructed using either full genomes or the partial RdRp, HSP70h and CP sequences with the Maximum Likelihood (ML) algorithm implemented in MEGA v. 7.1 (Molecular Evolutionary 
Genetics Analysis) [18], applying GTR+I+G, T92+G+I, T92+I and T92+G nucleotide substitution models, respectively, and 500 bootstrap replicates.

\subsection{Recombination Analysis}

The detection of recombination events was performed with RDP v.4.95 (Recombination Detection Program) [19] under default conditions, using an alignment of complete LChV1 genome sequences constructed with MAFFT v7 (Multiple Alignment using Fast Fourier Transform) [20].

\subsection{In Silico Evaluation of Published Primers for the Detection of LChV1}

The sequences of all primers reported to date for the detection of the virus were compared in silico with LChV1 complete genome sequences in order to determine the primer pair exhibiting the broadest detection range (Figure 4) [2,3,7,8,21-25].

\section{Results}

\subsection{HTS Analyses and Genome Assembly of LChV1 Isolates}

HTS of the G15 3 sample using the Ion Torrent platform provided a total of 3,971,532 sequence reads among which 32,358 or $0.81 \%$ were sRNAs of $21-24$ nt related to LChV1. Blast analysis of the contigs constructed by the de novo assembly of the reads indicated the presence of LChV1 along with other Prunus infecting viruses (Table 1).

A total of 71 LChV1 contigs (length higher than $50 \mathrm{nts}$ ) were identified by Blast analysis. In parallel, all sRNAs integrated in these contigs were mapped with the Geneious (Biomatters Ltd., Auckland, New Zealand) software on the complete genomes of the ITMAR, V2356 and UW2 isolates. A full coverage of the LChV1 genome was thus obtained using these sRNA sequences obtained by HTS. A relatively higher number of LChV1 sRNAs were allocated (+ and - polarity) in the $3^{\prime}$ region of the gRNA and in selected spots of the genome (Figure 1). The G15 3 genome sequence was confirmed with Sanger sequencing using specific primers (Table S1).

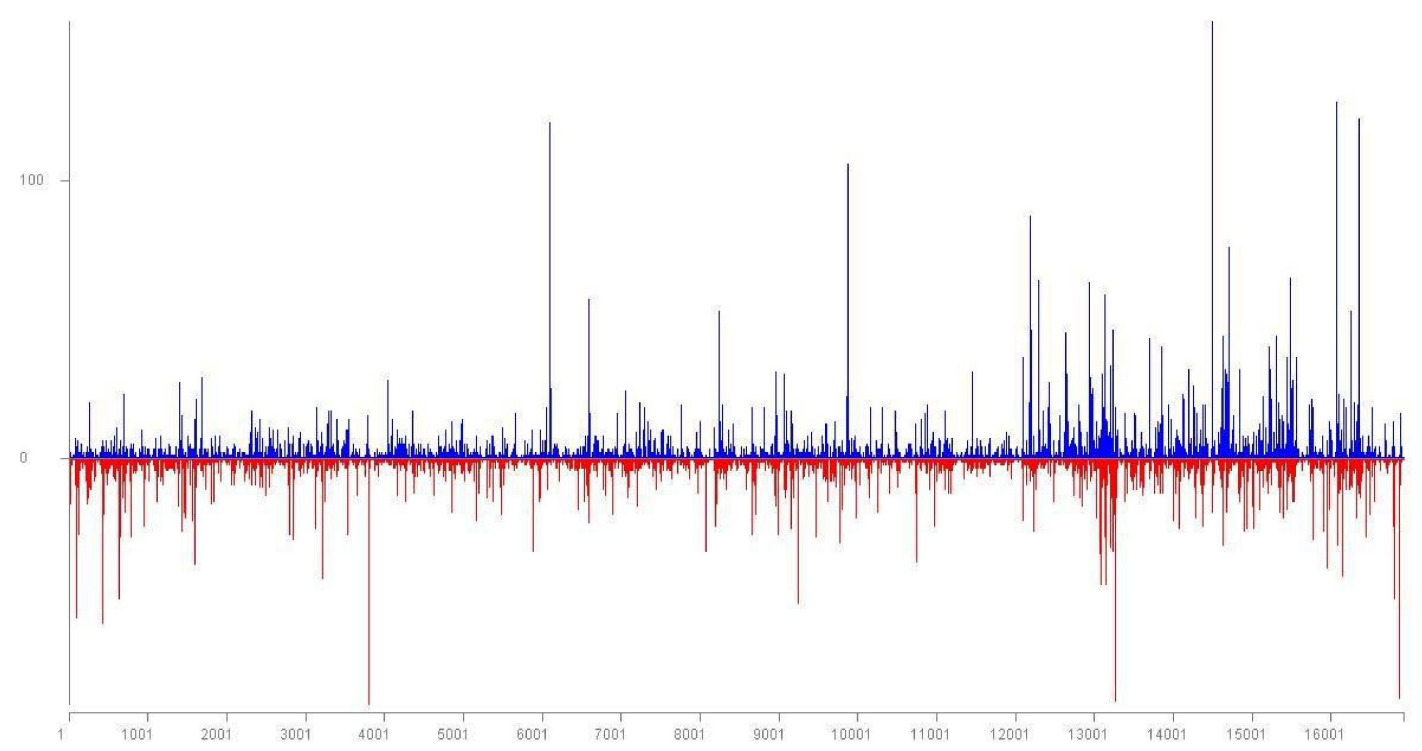

Figure 1. Location and frequency of Little cherry virus 1 (LChV1) small RNA reads on the LChV1 genomic RNA. Positive-sense reads are shown as blue bars; negative-sense reads are shown as red bars below the x-axis.

Following the de novo assembly of the LChV1 Kyoto-2 reads using CLC Genomics Workbench 9.0 (Qiagen Bioinformatics, Hilden, Germany), BlastN and BlastX analyses (cut-off value of $10^{-3}$ ) 
revealed the presence of contigs belonging to several well-known fruit tree viruses, including LChV1 (Table 1). Since the Blast analyses indicated that the LChV1 Kyoto-2 isolate was highly divergent from isolates present in GenBank, a specific effort was made to assemble the 15 LChV1 contigs identified (representing 1062 reads or $0.98 \%$ of total reads for this sample) in a scaffold covering most of the virus genome. Specific primers designed from the sequence of the contigs (Table S1) were used to fill the 10 gaps in the scaffold and sequence the missing genome ends.

De novo assembly with CLC Genomics Workbench (Qiagen Bioinformatics, Hilden, Germany) of 56,727,134 total RNA reads from the Greek sweet cherry sample C118 generated 3 almost full-genome sequences for LChV1 (0.07\% or 37,874 reads for C118-Iso1, $0.05 \%$ or 27,114 reads for C118-Iso13 and $0.04 \%$ or 25,494 reads for C118-Iso 15$)(16.662,16.812$ and $16.878 \mathrm{nt})$, along with other contigs belonging to several fruit tree viruses (Table 1). Blast analyses of these LChV1 contigs showed high similarities with three distinct LChV1 isolates, indicating a mixed infection with different viral genotypes.

Likewise, de novo assembly with CLC Genomics Workbench (Qiagen Bioinformatics, Hilden, Germany) of 54,261,654 total RNA reads from the Spanish sweet cherry sample P8 generated 2 full-genomes for LChV1 (7.2\% or 388,269 reads for P8-23 and 3.0\% or 161,431 reads for P8-42) (16.938 and $16.963 \mathrm{nt}$ ), along with other contigs belonging to several fruit tree viruses (Table 1). Blast analyses of these contigs showed high similarities with two different LChV1 isolates, indicating a mixed infection with different viral genotypes.

\subsection{Genomic Organization and Sequence Similarities of the New LChV1 Isolates}

LChV1 G15 3 (16.880 nt) and Kyoto-2 (16.927 nt) genomic sequences were deposited in the GenBank under the accession numbers LN794218 and MG934545, respectively. Based on Blast analysis these two isolates represent divergent genotypes of LChV1 and therefore their genome organization was further analyzed in detail. The variants obtained from the C118 (MH364114, MH364115, MH364116) and P8 (MH300060, MH300061) sources had the typical genome organization of LChV1 and showed high identity rates (90-98\% in nts) with already sequenced variants present in GenBank (Table S2).

The G15 3 and Kyoto-2 genomes showed overall nucleotide identity percentages that ranged between $72-73 \%$ and $75-77 \%$, respectively, with the other available LChV1 full genomes, whereas they shared $73 \%$ nt identity (Table 2). The amino acid identity percentages ranged between 65-92\% and 70-94\% for G15 3 and Kyoto-2, respectively, with the other available full genomes and 68-92\% between them. In the $5^{\prime}$ Untranslated Region (UTR) of the G15 3 and Kyoto-2 genomes a limited number of indel polymorphisms were observed when compared to reference sequences. In fact, this small genomic region was found to be highly conserved between LChV1 isolates. ORF1a, which encodes a large protein with P-PRO, MET and HEL conserved domains, shares 70-72\% (G15 3) and $71-76 \%$ (Kyoto-2) identities in nt with the already characterized LChV1 isolates (Table 2). ORF1b, which encodes the viral RdRp shares higher nucleotide similarities with other isolates, 80-81\% and 79-83\% for G15 3 and Kyoto-2, respectively (Table 2). The P4 proteins of the G15 3 and Kyoto-2 isolates are 5 amino acids (aa) shorter than those of the UW2 and ITMAR isolates, as a point mutation of a thymine $(\mathrm{T})$ to adenine $(\mathrm{A})$ results in the creation of a premature stop codon. The genomic sequence encoding this protein shares respectively 70-81\% (G15 3) and 78-81\% (Kyoto-2) nt identity with other isolates. Both for G153 and Kyoto-2, a 1 nt insertion within ORF3 (encoding the HSP70 homolog) results in a frameshift and the production of a 67 aminoacids shorter protein when compared to the UW2 and ITMAR isolates. In ORF4 (P61) and ORF5 (CP), the level of nucleotide divergences with other LChV1 isolates remains high, reaching only for the P61 ORF 72-74\% nt identity (G15 3) to 73-76\% (Kyoto-2) and for the CP gene 70-72\%nt identity (G15 3) to 71-78\% (Kyoto-2) (Table 2). In both isolates a $1 \mathrm{nt}$ deletion towards the $3^{\prime}$ end of ORF6 (CPm) leads again to premature termination and, in this case, to a protein 2 aminoacids shorter as compared to the UW2 and ITMAR isolates. Again, high divergence levels are observed in this ORF (68-70\% and 70-73\% nt identity with other LChV1 isolates for the G15 3 and Kyoto-2 isolates, respectively) (Table 2). The indel polymorphisms and the mutations 
mentioned above were also observed in the rest of the isolates sequenced in the present study, as well as in all recently characterized LChV1 isolates [3,5-8]. An ORF finder analysis placed the beginning of ORF7 (P21) at position 15.285 of the genome when the alignment of all available full-length genomes was used (position 15.254 on the G15 3 genome). However, ORF7 for ITMAR and UW2 starts only at position 15.436 , because a $C$ insertion at position 15.402 results in a frameshift in the $5^{\prime}$ region of the ORF, so that initiation is only possible on the downstream methionine, resulting in a 50aa shorter protein. Similarly, ORF8 (P27) starts at position 16.018 of the alignment of full genomes, whereas for the YD isolate the insertion of an A at position 16.044 forces initiation of the ORF at a downstream methionine at position 16.076, resulting in a 19aa shorter protein. For both G15 3 and Kyoto-2, the level of nucleotide divergence with other isolates was higher in ORF8 (76-78\% for G15 3 and 77-85\% for Kyoto-2, respectively) than for ORF7 (71-75\% for G15 3 and 74-81\% for Kyoto-2, respectively) (Table 2). Finally, in the first 50 nucleotides of the $3^{\prime}$ UTR ( 200 nt long) a high variability is observed between all LChV1 isolates (Figure 2). In addition, indel polymorphisms were observed in several positions of the $3^{\prime}$ UTR. In G15 3, deletions were observed in a significant number of positions within the $3^{\prime}$ UTR, including $13 \mathrm{nt}$ and $23 \mathrm{nt}$ long deletions. Similar deletions were only observed in LChV1 isolates from India (Figure 2). The divergent region is followed by a highly conserved region among all isolates.

Table 2. Nucleotide and aminoacid identity percentages (\%) between the G15 3 and Kyoto-2 isolates with all other fully sequenced LChV1 isolates.

\begin{tabular}{|c|c|c|c|c|c|c|c|c|}
\hline \multirow{2}{*}{$\frac{\text { G15 } 3}{\text { Genomic Region }}$} & \multicolumn{8}{|c|}{ Identity in nt (aa) with LChV-1 Isolates } \\
\hline & ITMAR & UW2 & V2356 & YD & JERTE & PONFERRADA & TAIAN & KYOTO-2 \\
\hline Full genome & 72 & 72 & 72 & 73 & 73 & 73 & 73 & 73 \\
\hline ORF1a (P-PRO, MET \& HEL) & $70(75)$ & $70(76)$ & $72(76)$ & $72(76)$ & $72(77)$ & $71(76)$ & $71(76)$ & $71(76)$ \\
\hline ORF1b (RdRp) & $80(90)$ & $80(92)$ & $81(92)$ & $80(92)$ & $80(91)$ & $81(92)$ & $80(90)$ & $80(92)$ \\
\hline ORF2 $(\mathrm{p} 4)$ & $72(67)$ & $70(67)$ & $76(77)$ & $76(70)$ & $74(70)$ & $70(67)$ & $73(74)$ & $81(83)$ \\
\hline ORF3 (HSP70h) & $75(79)$ & $76(81)$ & $74(81)$ & $76(83)$ & $76(83)$ & $76(83)$ & $76(83)$ & $76(81)$ \\
\hline ORF4 (p61) & $72(75)$ & $72(75)$ & $74(76)$ & $72(75)$ & $73(74)$ & $73(74)$ & $73(74)$ & $73(74)$ \\
\hline ORF5 (CP) & $72(73)$ & $72(72)$ & $70(72)$ & $72(73)$ & $72(74)$ & $72(74)$ & $72(74)$ & $71(72)$ \\
\hline ORF6 (CPm) & $69(66)$ & $70(68)$ & $68(65)$ & $69(68)$ & $69(67)$ & $69(67)$ & $70(67)$ & $70(68)$ \\
\hline ORF7 (p21) & $76(88)$ & $76(87)$ & $76(85)$ & $78(87)$ & $78(88)$ & $78(88)$ & $78(88)$ & $77(85)$ \\
\hline ORF8 (p27) & $71(69)$ & $73(74)$ & $74(74)$ & $73(71)$ & $73(75)$ & $73(75)$ & $72(75)$ & $75(71)$ \\
\hline KYOTO-2 & \multicolumn{8}{|c|}{ Identity in nt (aa) with LChV-1 Isolates } \\
\hline Genomic Region & ITMAR & UW2 & V2356 & YD & JERTE & PONFERRADA & TAIAN & G15 3 \\
\hline Full genome & 75 & 75 & 77 & 77 & 77 & 76 & 77 & 73 \\
\hline ORF1a (P-PRO, MT \& HEL) & $74(79)$ & $74(80)$ & $76(83)$ & $75(83)$ & $75(83)$ & $75(82)$ & $75(82)$ & $71(76)$ \\
\hline ORF1b (RdRp) & $79(91)$ & $80(93)$ & $83(94)$ & $80(94)$ & $81(93)$ & $81(93)$ & $81(93)$ & $80(92)$ \\
\hline ORF2 $(\mathrm{p} 4)$ & $79(70)$ & $82(77)$ & $81(80)$ & $81(70)$ & $79(70)$ & $78(74)$ & $78(74)$ & $81(83)$ \\
\hline ORF3 (HSP70h) & $77(83)$ & $78(84)$ & $79(85)$ & $79(86)$ & $80(87)$ & $80(86)$ & $80(87)$ & $76(81)$ \\
\hline ORF4 (p61) & $74(79)$ & $74(79)$ & $76(80)$ & $76(79)$ & 75 (79) & $76(79)$ & $75(79)$ & $73(74)$ \\
\hline ORF5 (CP) & $74(76)$ & $74(78)$ & $73(75)$ & $77(78)$ & 77 (79) & $77(78)$ & $78(78)$ & $71(72)$ \\
\hline ORF6 (CPm) & $72(70)$ & $73(71)$ & $73(72)$ & $73(72)$ & $73(71)$ & $73(71)$ & $73(70)$ & $70(68)$ \\
\hline ORF7 (p21) & $81(90)$ & $80(90)$ & $82(93)$ & $84(94)$ & $84(92)$ & $84(92)$ & $85(92)$ & $77(85)$ \\
\hline ORF8 (p27) & $74(75)$ & $79(82)$ & $81(85)$ & $80(85)$ & $79(82)$ & $79(81)$ & $79(82)$ & $75(71)$ \\
\hline
\end{tabular}

The following isolates sequences, obtained from GenBank, were used ITMAR (EU715989), UW2 (Y10237), V2356 (JX669615), YD (KR080325), JERTE (KX192366), PONFERRADA (KX192367), TAIAN (KR736335).

\subsection{Intra-Host Genetic Diversity of LChV1}

A mixed infection with different LChV1 genotypes was identified in samples C118 and P8 from Greece and Spain, respectively. The C118-Iso1 sequence shares 99\% identity with the G15 3 described in the present study. The C118-Iso13 sequence shares 98\% identity with the V2356 isolate while the C118-Iso15 sequence shares $94 \%$ and $92 \%$ identity, respectively, with isolates UW2 and ITMAR (Table S2). The P8-23 sequence shares 97\% identity with the Ponferrada, Jerte and Taian isolates. The P8-42 shares 90\% identity with the V2356 isolate (Table S2). The co-infection of the sweet cherry trees with different LChV1 isolates was confirmed by RT-PCR amplification and RFLP analysis of the amplified CP gene (Supplementary Materials). 

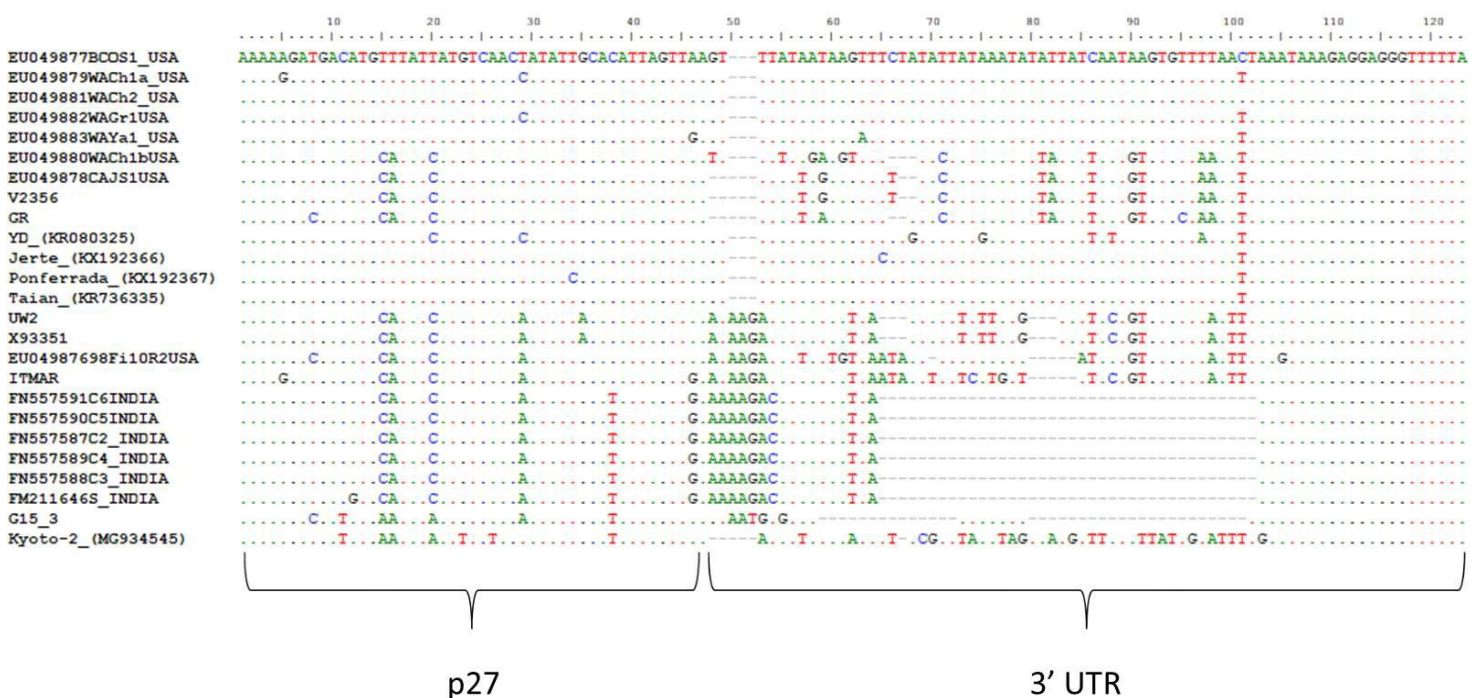

Figure 2. Multiple sequence alignment representing the beginning of the $3^{\prime}$ Untranslated Region (UTR). All available in GenBank LChV1 isolates with deposited sequences from this genomic region, were used.

\subsection{Recombination Analysis}

A recombination analysis performed with RDP4 on an alignment of all available full-length LChV1 genomic sequences revealed the presence of two recombination events in the $3^{\prime}$ part of the ITMAR genome and UW2 and Jerte are presumed to be the parental isolates (Figure 3). These events were detected by six out of the seven algorithms used (RDP, GENECONV, BootScan, MaxChi, Chimaera, 3Seq) [26-30]. No clear evidence of recombination was observed for the LChV1 sequences reported in the present study.
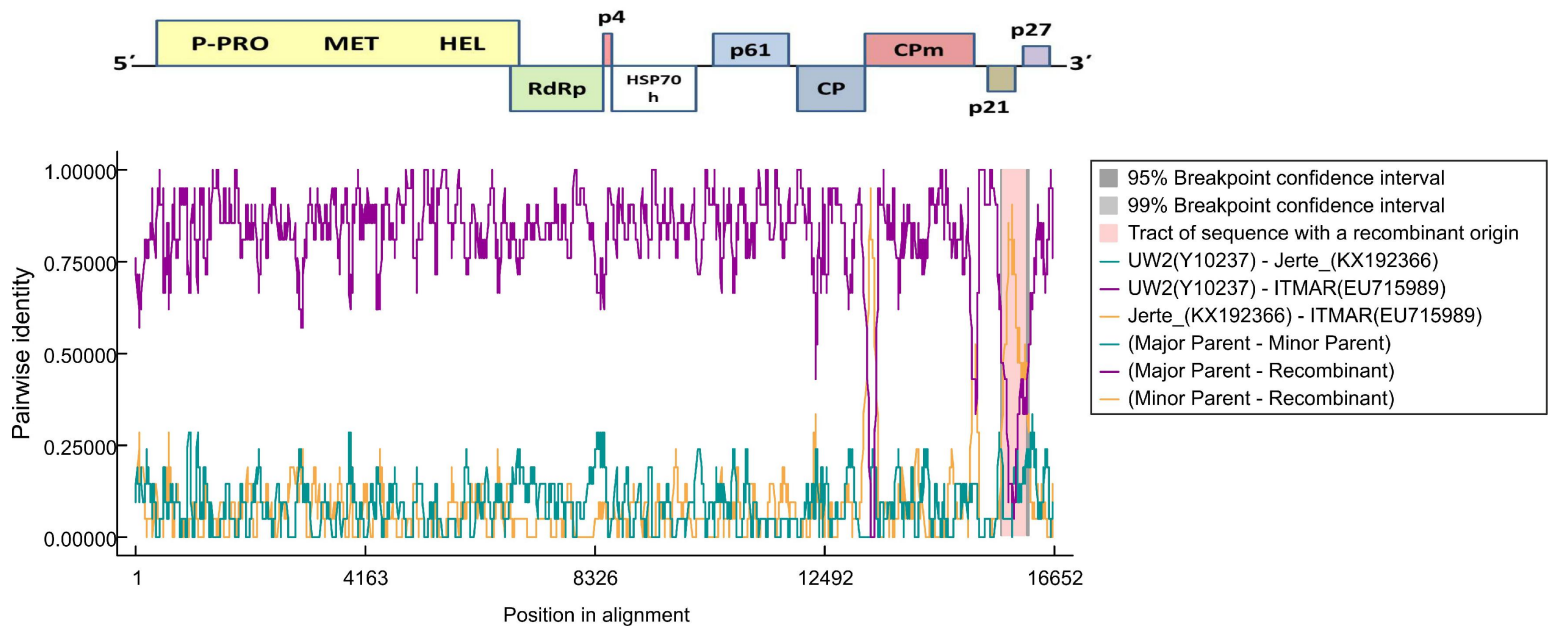

Figure 3. Recombination events predicted by RDP v.4.95 (Recombination Detection Program) in the $3^{\prime}$ end of the ITMAR isolate of LChV1. Lines in the graph give the pairwise identity percentage in the respective alignment position. The recombinant part is indicated by a frame and the breakpoints by darker background. LChV's genome is given above the graph.

\subsection{Phylogenetic Analysis}

A full-length genome phylogenetic analysis clustered all LChV1 isolates (available from GenBank and the reported here) in 5 distinct clusters (Figure 4). In order to compare these results with the 
grouping proposed in a previous study [8] phylogenetic trees were also constructed using partial RdRp ( 700 nt), HSP70h (500 nt) and CP (550 nt) sequences including the partial sequences used in that 2015 study. Comparison of the trees showed that all four previously identified LChV1 clusters were comparably detected in the new analysis but that a fifth cluster was identified formed by the single Kyoto-2 isolate (Figure 4 and Figure S1).

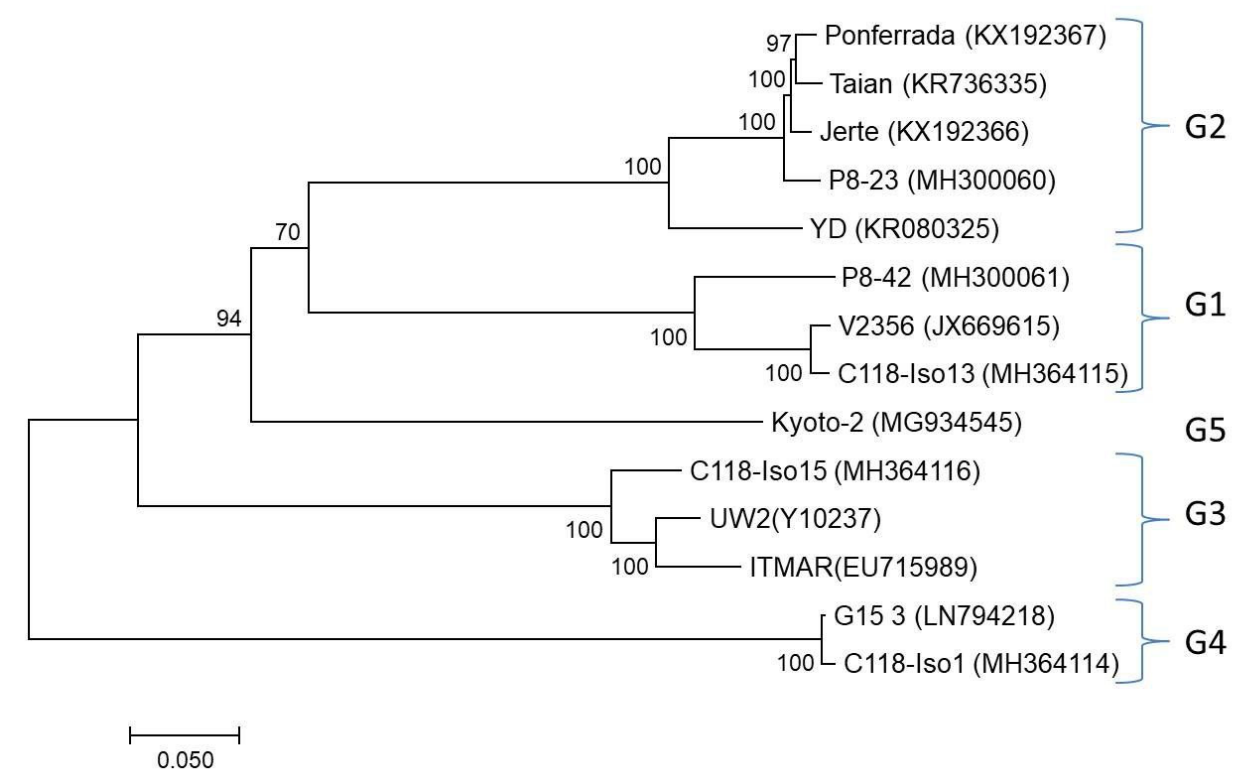

Figure 4. Maximum likelihood phylogenetic tree inferred from the complete nucleotide sequences of LChV1 isolates. All isolates are reported with their names followed by their accession numbers. The tree is midpoint-rooted. The numbers above or below each branch are the nonparametric bootstrap (NPB) values given as percentages of 500 replicates. Only NPB values with $p>70$ are shown.

\subsection{Detection Range of LChV1 Specific Primers}

To determine the most suitable primer pair for the accurate detection of all isolates of LChV1, detection primer pairs reported in the literature were retrieved and compared with all available full-length genomic sequences (Figure 5). In most cases, these detection primers showed either multiple mismatches with some isolates (up to 10-12 mismatches for the 6 for primer of Matic et al. [2]) or mismatches affecting the two 3'-most nucleotides of the primer (in particular the LCUW7090 primer of Bajet et al. [22]). Such mismatches are highly likely to either preclude amplification of some isolates or severely affect the sensitivity of detection. Taking into account a conservation rule of less than 3 mismatches for a primer with any particular isolate and of no mismatch affecting the $3^{\prime}$ nucleotide of a primer, only two primer pairs are expected to be able to show very broad amplification of all LChV1 isolates (Figure 5), the LChV1-upnest and LChV1-donest pair developed and used in a nested RT-PCR detection scheme targeting the HSP70h [8] and the complex primers mix (LCh-A, LCh-B, LCh-C, LCh-D, LCh-DF, LCh-DR) used in a real-time RT-PCR detection scheme targeting the CP [25]. 


\begin{tabular}{|c|c|c|c|c|c|}
\hline \multicolumn{3}{|c|}{ p27 + 3'UTR (Rott and Jelkmann, 2001) } & \multicolumn{3}{|c|}{ replicase (Bajet et al, 2008) } \\
\hline Kyoto-2 & TCCGCTTGAAACATCTAATCCA 3 & AGAGGAGGGTTTTTATACCGCTTACC 1 & Kyoto-2 & GTTTATCTTCTATTGATTA] 6 & GAGATGTATGGAACCGAGTC 2 \\
\hline & TTCGTTTGAAACATTTGATIICA 8 & \multirow{2}{*}{$\begin{array}{l}\text { AGAGGAGGGTTTTTATACCGCTTACC } 1 \\
\text { AGAGGAGGGTTTTTATACCGCTRACC } 1\end{array}$} & v2356 & GGTTGTCCTCAGTTGATTAC 1 & GAGATGCATGGAACCAAGTC 2 \\
\hline & TTCGTTTGAAGCATTTGAT ICA 7 & & YD & GTTTGTCTTCTGTAGATTAII 5 & GAGGTGCATGGAACCCAGCC 2 \\
\hline Jerte & TTCGTTTGAAACATTTAAT CA 7 & 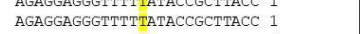 & Jerte & GTTTGTCTTCTGTTGATT 5 & GAGATGTATGGAACCTAGTC 2 \\
\hline Taian & TTCGTTTGAAACATCTAAT CA 6 & AGAGGAGGGTTTTTATACCGCTTACC 1 & Taian & GTTTGTCTTCTGTTGATT 5 & GAGATGTATGGAGCCTAGTC 3 \\
\hline Ponferrada : & TTCGTTTGAAACATTTAAT CA 7 & AGAGGAGGGTTTTTATACCGCTTACC 1 & Ponferrada & GTTTGTCTTCTGTTGATT 5 & GAGATGTATGGAGCCTAGTC 3 \\
\hline & TCCGCCTGAAGCACCTAATCCA 0 & & & GGTTGTCCTCGGTTGATTAC 0 & GAGATGTATGGAACCAAGCC 0 \\
\hline ITMAR & TTCGCTTGAAGCACCTAATCCA 2 & & ITMAR & GGTTGTCCTCGGTTGATTAC 0 & GAGATGCATGGAACCAAGCC 1 \\
\hline G153 & TCCGTTTGAAATATTTAATIICA 7 & $\begin{array}{l}\text { AGAGGAGGGTTTTAATACCGCTTACC } 1 \\
\text { AGAGGAGGGTTTTATACCGCTTACC } 1\end{array}$ & G153 & GGTTGTCTTCTGTTGATTAM 3 & G] GATGTATGGAACCGAGTC 3 \\
\hline IChV-1 F: & TCCGCCTGAAGCACCTAATCCA & $\begin{array}{l}\text { AGAGGAGGGTTTTATACCGCTTACC } 1 \\
\text { AGAGGAGGGTTTTATACCGCTTACC :IChV-1 R }\end{array}$ & \multirow{10}{*}{$\begin{array}{l}\text { Kyoto-2 } \\
\text { V2356 } \\
\text { YD } \\
\text { Jerte } \\
\text { Taian } \\
\text { Ponferrada } \\
\text { UW2 } \\
\text { ITMAR } \\
\text { G153 }\end{array}$} & GGTTGTCCTCGGTTGATTAC & GAGATGTATGGAACCAAGCC :ICUWC \\
\hline \multicolumn{3}{|c|}{ CPm (Matic et al, 2009) } & & \multicolumn{2}{|c|}{$\begin{array}{l}\text { p27 + } 3 \text { G'UTR } \\
\text { GTARTAAATTCACTGCAAGTG } 3 \text { GCATATATAAA---AAATAAAA-GGTG } 0\end{array}$} \\
\hline & ACTGACGGAAATAAGTGAAGT 10 & ICAAGAGCACGAGGTGATTGG 2 & & GTTATAGAGTTCACTGCAAGTG 1 & GCATATATATATAAAAATAAAA-GGTG 3 \\
\hline V2356 & ACTTACTGACATAAATGAAGT 8 & \multirow{2}{*}{$\begin{array}{l}\text { CAAGAGGCACGAGGTGATTGG } 2 \\
\text { TCAAGAGCACGAAGTGATTGG } 0\end{array}$} & & GTTATCGAATTCACTGCTAGTG 2 & GCATATATAAA--AAATAAAA-GGTG 0 \\
\hline & TCTTACAGAGATAGGAGATGT 12 & & & GTTATCGAATTCACTGCAAGTG 1 & GCATATATATA--AAATAAAA-GGTG 0 \\
\hline Jerte & ACTTACGGAGATAAGAGATGTG 10 & \multirow{2}{*}{ TCAAGAGCACGAAGTGATTGG 0} & & GTTATCGAATTCACTGCAAGTG 1 & GCATATATAAA--AAATAAAA-GGTG 0 \\
\hline Taian & ACTTACAGAGATAAGAGATGTG 10 & & & GTTATCGAATTCACTGCAAGTG 1 & GCATATATATA--AAATAAAA-GGTG 0 \\
\hline Ponf & 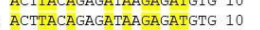 & $\begin{array}{l}\text { TCAAGAGGACGAAGTGATTGG } 0 \\
\text { TCAAGACACAAAGTARTGG } \\
0\end{array}$ & & GTTATAGAATTCACTGCAAGTG 0 & GCATATATAAA--AAATAAAA-GGTG 0 \\
\hline UW2 & CCTTTCTGAGGTGAATGGAGTG1 & CAAAGAGCACGAAGTGATTGG 1 & & GTTATAGAATTCACTGCAAGTG 0 & GCATATATAAA--AAATAAAA-GGTG 0 \\
\hline ITMAR & CCTCTCTGAGGTGAATGGAGTGO & $\begin{array}{l}\text { ICAAGAGCACGAAGTGATTGG } 1 \\
\text { TCAAGAGCACGAAGTGATTGG } 0\end{array}$ & & GTCGTCGAGTTCACTGCCAGTG 5 & \\
\hline G153 & ATTAACCGAAGTAAGTAAAETI 12 & \multirow{2}{*}{$\begin{array}{l}\text { CAAGAGCACGAAGTGATAGG } 2 \\
\text { TCAAGAGCACGAAGTGATTGG }: 2 \mathrm{rev}\end{array}$} & $16659:$ & GTTATAGAATTCACTGCAAGTG & GCATATATAAAAAATAAAAGGTG $: 3 \mathrm{BC}$ \\
\hline 6for: & CCTCTCTGAGGTGAATGGAGTG & & & CP (Zong & et al, 2015) \\
\hline & polymerase (Candre & esse et al, 2013) & & AAGCAGGACACTGCTAGWGA 14 & CGCTACTCCAATGCATAAAG 2 \\
\hline Kyoto-2 & ACGCTTC-GGTTTGAATATTCA-GAT & & & 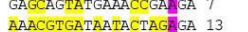 & $\begin{array}{l}\text { GGTACTCCAATCCATAAAG } 3 \\
\text { GCTACTCCGATGCATAAAG } 4\end{array}$ \\
\hline v2356 & ACTCTTC-GGTTTGAATATTCA-GAT & & & ACACGTAGTGAGGGTAGM GA 12 & GCTACACCGATGCATAAAG 3 \\
\hline & ACTCTTC-GATTCGAGTATTCT-GAT & TGGAACCCAGCCGTTTGGC 1 & Tai. & 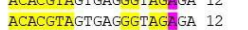 & GCTACACCGATGCATAAAG 3 \\
\hline Jerte & ACTCTTC-GATTCGAGTATTCT-GAT & TGGAACCTAGTCGTTTGGC 1 & Ponfer & ACACGTAGTGAGGGTAGEGA 12 & GCTACACCGATGCATAAAG 3 \\
\hline Taian & ACTCTTC-GATTCGAGTATTCT-GAT & TGGAGCCTAGTCGTTTGGC 2 & UW2 & GACGAGCGTGAGATTGAGGA 0 & CGCTACACCAATGCACAAAG 0 \\
\hline Ponferrada & ACTCTTC-GATTCGAGTATTCT-GAT & TGGAGCCTAGTCGTTTGGC 2 & ITMAR & GACGAGCGTGAGACTGAGGA 1 & СGCTACACCAATGCACAAAG 0 \\
\hline Uw2 & АСТСTCC-GTTTTGAGTATTCT-GAT & TGGAACCAAGCCGTTTGGC 0 & G153 & GATGATGAAAAGATTGGAA 9 & СGCTACACCGATGCACAAAG 1 \\
\hline ITMAR & ACTCTCCCGTTTTGAGTATTCCCGAT & TGGAACCAAGCCGTTTGGC 0 & LChV1-s: & GACGAGCGTGAGATTGAGGA & CGCTACACCAATGCACAAAG: IChV1-A \\
\hline$\frac{\mathrm{G} 153}{\mathrm{RdRp}-\mathrm{F} 2 \mathrm{i}: 2}$ & $\begin{array}{l}\text { ACGCTTC-GGTTTGAATATTCC-GA. } \\
\text { ACTCTYCGDTTBGADTATTCIGAT }\end{array}$ & $\frac{\text { TGGAACCGAGTCGTCTAGC } 3}{\text { TGGAACCAAGYCGTTTGGC:RARg }}$ & & CP (Glas: & ssa et al, 2015) \\
\hline & HSP70h (Katsiani & et $\mathrm{al}, 2015$ ) & Kyoto-2 & TTAAGAAAAGCTCAGGGGTGC 4 & GATACTGATACAACTAGCTCG 2 \\
\hline & & GAAGATCAACACAAACTTAAG 0 & v235 & TCAAGAAAAGTTCTGGTGTGC 0 & GATACTGATACGTCTAGCTCG \\
\hline & GATTTAAAACGTTGGGTAGG 0 & GAAGATCAACATADACTTAAG 0 & & TCAAGAAAAGTTCTG & \\
\hline & $\begin{array}{ll}\text { A.CGITGGGIAGG } \\
\text { ACGCTGGTAGG } 0\end{array}$ & GAAGATCAACP & & & \\
\hline Jerte & $\begin{array}{l}\text { GATAAAACG } \\
\text { GATTTAAAGCGTGGGTAGG } 0\end{array}$ & GAGGATCAACATAAACTTAAG 0 & & TIR & \\
\hline Taian & $\begin{array}{l}\text { GATTTAAAGCGTGGGGTAGG } 0 \\
\text { GATTTAAAGCGTGGGTAGG } 0\end{array}$ & GAGGAICAFCATHACIIAHG O & errada & TIAA & \\
\hline Ponferrada & $\begin{array}{l}\text { GATTTAAAGCGTGGGGITGG } 0 \\
\text { GATTTAAAGCGTTGGGAGG } 0\end{array}$ & GAGGATC & uW2 & TCAAGA & \\
\hline & $\begin{array}{l}\text { GATTTAAAACGTTGGGITAGG } 0 \\
\text { GATTTAAAACGTGGGGAGG } 0 \\
0\end{array}$ & $\begin{array}{l}\text { GAGGATC } \\
\text { GAAGATC }\end{array}$ & ITMAR & TCAAGAAAAGTTCTGGTGTGC 0 & GATACT GATACGTCTAGCTCG 0 \\
\hline & $\begin{array}{l}\text { GATTTAAAACGTTGGGTAGG } 0 \\
0\end{array}$ & 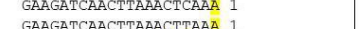 & G153 & TCAAGAAAGCTGCAGGAGTGC 5 & GATACTGATACGACTAGCTCG 1 \\
\hline & GATTTAAAACGTTGGGTAGG 0 & $\begin{array}{l}\text { GAAGATACAACTAAAACTTAAAA } 1 \\
\text { GAAGACAACACAATTAAAG } \\
2\end{array}$ & $1 \mathrm{LC} \_12776 \mathrm{~F}$ & $\because$ TCAAGAAAAGTTCTGGTGTGC & GATACTGATACGTCTAGCTCG :1LC_13223R \\
\hline L153 & $\begin{array}{l}\text { GAITTAAAACGITGGGITGG } \\
\text { St: GATTTAARCGTGGGTGG }\end{array}$ & GARGATCAACWYAAACTTAAG :IChV1-donest & & CP (Kats & siani et al, 2018) \\
\hline & & et al, 2016) & Kyoto-2 & CCAATGCATAAAGCTCACATGA 1 & $\begin{array}{l}\text { TATTAGGACCACGTCGTGGT } 1 \\
\text { TATTAGGACCACGTCGAGGT } 1\end{array}$ \\
\hline & AATGCATAAAGC & GGT 1 & & CCAATGCATAAAGCTCATATGA 0 & \\
\hline & CAATGCATAAAGCTCATATGA 2 & & & CCGATGCATAAAGCTCATATGA 1 & $\begin{array}{l}\text { TATTGGGACCACTCGCGGT } \\
\text { TATTGGGACCACGTCGCGGT }\end{array}$ \\
\hline & CCGATGCATAAAGCTCATATGA 3 & TGGGACC & Jerte & CCGATGCATAAAGCTCATATGA 1 & $\begin{array}{l}\text { TAATGGGGACCACTCGGGGT } 1 \\
\text { TATPAGGACCACGTCGGGT }\end{array}$ \\
\hline & CCGATGCATAAAGCTCATATGA 3 & TATTGGGACCACGTCGCGGT 1 & & CCGATGCATAAAGCTCACATGA 2 & TATTGGGACCACGTCGCGGT 1 \\
\hline & CCGATGCATAAAGCTCACATGA 4 & TATTAGGACCACGTCGCGGT 0 & $\begin{array}{l}\text { Ponferr } \\
\text { UW2 }\end{array}$ & $\begin{array}{l}\text { CCGATGCATAAAGCTCACATGA } 2 \\
\text { CCAATGCACAAAGCACATATGA } 0\end{array}$ & TATTAGGACCACGTCGCGGT 0 \\
\hline Ponfe & CCGATGCATAAAGCTCACATGA 4 & TATTGGGACCACGTCGCGGT 1 & & 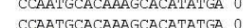 & TATTAGGACCACGTCGCGGT 0 \\
\hline UW2 & CCAATGCACAAAGCACATATGA 0 & TATTAGGACCACGTCGCGGT 0 & 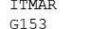 & $\begin{array}{l}\text { CCAAAGCACAAAAGCACATTTEA } 0 \\
\text { CCGATGCACAAAGCATCAATGA } 1\end{array}$ & TGTTAGGACCACGTCGTGGT 0 \\
\hline & & TATTAGGACCACGTCGCGGT 0 & & CCGATGCACAAAGCATCAATGA 1 & TATTAGGACCACGTCGCGGT :IC \\
\hline G15 & & & & $\begin{array}{l}\text { CCAATGCACAAAGCACATI } \\
\text { CCAAGCATAAGCTCATZ }\end{array}$ & TATTGGGACCACGTCGAGGT : ICh-D \\
\hline & CCAATGCACAAAGCACATATGA & TATTAGGACCACGTCGCGGT: $: R$ & ICh-DF: & 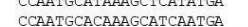 & TGTTAGGACCACGTCGTGGT : ICh-DR \\
\hline
\end{tabular}

Figure 5. Multiple sequence alignments of the primer binding regions for the detection of LChV1. The position and number of mismatches with the full genome LChV1 isolates representing all phylogenetic groups are indicated. In red, violet and yellow color are presented the mismatches of the primer affecting the first $3^{\prime}$-most nucleotide, the second and third $3^{\prime}$-most nucleotide as well as all other nucleotides, respectively.

\section{Discussion}

In this study the complete genome sequences of several LChV1 isolates from three countries was determined. For this purpose, different HTS approaches, which offer fast and accurate determination of genomic sequences, were used [3,31]. Based on the obtained HTS data we were able to obtain the full genomes for two novel and divergent LChV1 isolates, G15 3 and Kyoto-2, as well as the genomes of variants sharing high similarities with previously described ones (C118-Iso1, -Iso13, -Iso15, P8-23, P8-42).

Phylogenetic analysis of the obtained genomic sequences confirmed the existence of high genetic diversity among LChV-1 isolates, which could be clustered in five distinct clades that are not correlated with the geographic origin of the isolates (Figure 4). Interestingly, mixed infections of sweet cherry trees involving different LChV1 genotypes were identified here for the first time. Since no known vector has been found for LChV1, the coexistence of these different virus variants could be attributed to grafting practices involving infected plant material. These mixed infections might have implications on the pathogenicity of the virus and could lead to recombination events as has already been reported for LChV1 [8] and is further described here.

The demarcation criteria of viral species within the family Closteroviridae are based on molecular and biological characteristics as well as on phylogenetic relationships [32]. Due to the high genetic 
diversity observed for several members of the family, the level of sequence divergence was recently raised from 10 to $25 \%$ aa in phylogenetically informative proteins (RdRp, HSP70h, or CP) for species demarcation [32]. Isolate G15 3 is thus close to this species demarcation level in its HSP70h (17-21\%), while its CP exceeds it (26-28\% with all isolates) (Table 2 and Table S2). However, its divergence with all other LChV1 isolates is much lower in the RdRp (8-10\%), confirming that G15 3 belongs to the LChV1 species and represents the first fully characterized isolate of a fourth phylogenetic group, genetically distinct from all others reported so far. Similarly, the Kyoto-2 isolate represents the first fully characterized isolate of a fifth group since its divergence with other isolates in the RdRp was 6-9\%, in HSP70h 13-19\% and in CP 28\% with G15 3 and 21-25\% with all other isolates.

Sequence comparisons of all available LChV1 isolates have shown a high conservation in the $5^{\prime}$ UTR and in the $3^{\prime}$-most part of the $3^{\prime}$ UTRs, whereas, a significant number of indel polymorphisms were observed in the $5^{\prime}$-most part of the $3^{\prime}$ UTR of isolate G15 3. Apart from G15 3, deletions in the same positions are also observed in a LChV1 group of isolates from India for which only very partial sequence (409 nt) is available. However, G15 3 was found to be genetically distant from these isolates (nucleotide divergence $28-29 \%$ in the sequenced region). Similar large indel polymorphisms have also been reported in the $3^{\prime}$ UTR of some Grapevine leafroll-associated virus 2 (GLRaV2) variants [33]. Similar to the situation for GLRaV2, a highly conserved region was identified in LChV1 downstream of the polymorphic region of the $3^{\prime}$ UTR. It is known that the $3^{\prime}$ UTR of positive strand RNA viruses generally contains regulatory sequences essential for the synthesis of the complementary minus strand $[33,34]$. However, the biological significance of the upstream polymorphisms, if any, remains unknown although it has been speculated that differences in the $3^{\prime}$ UTR might affect the efficiency of the viral genome replication [33].

Within both the G15 3 and Kyoto-2 sequences a small number of shared polymorphisms confirmed by Sanger sequencing were observed affecting several ORFs and leading to either shorter or longer proteins as compared to some other reference isolates. In particular, proteins $\mathrm{p} 4$ and $\mathrm{CPm}$ are slightly smaller for the Kyoto-2 and G15 3 isolates as compared to the UW2 and ITMAR isolates while their HSP70h is truncated by 67 aminoacids. The same polymorphisms were observed in all other fully characterized LChV1 isolates as well as in some partial sequences [3,5-8]. It is known that the HSP70h is involved in cell-to-cell movement, assembly of the complexes of the subunits for viral replication and/or synthesis of subgenomic (sg) RNAs, as well as the assembly of the viral particle [35-37]. The loss of the C-terminal part of HSP70h in these isolates indicates that this part of the protein is possibly not essential for its function. This finding warrants further studies since it might endow these isolates novel biological properties. Variation in the size of some proteins has also been reported between Citrus tristeza virus (CTV) isolates [38].

Proteins p21 and p27, located at the $3^{\prime}$-portion of the genome, were found to be conserved among the LChV1 isolates, whereas no sequence similarity was seen with the similarly sized proteins encoded by the 3 '-portions of the genomes of other velariviruses despite extensive BLAST searches). The high variability of these proteins between viruses could reflect specific host adaptation functions such as countering antiviral defenses as found in other closteroviruses [39,40]. Recent preliminary data indicated that p21 is putatively acting as an RNA silencing suppressor [41] however further studies are needed in order to clearly define the role of these two divergent proteins on the infection cycle of LChV1.

The high genetic diversity of LChV-1 and the highly divergent isolates reported here could affect the reliable detection of viral isolates. Indeed, an in silico analysis of the detection primer pairs reported in nine different publications revealed in most cases a significant number of mismatches with at least some LChV1 isolates, to the extent that the amplification of these isolates is likely compromised, limiting the polyvalence of the detection assays employing them (Figure 5). This analysis also showed that the primers used in two detection schemes targeting the HSP70h or the CP [8,25], likely exhibit the highest detection range. 
Although growing evidence suggests that LChV1 isolates could be largely latent in many of their hosts it is still included in many certification and quarantine schemes and several LChV1 isolates have been tentatively associated with specific syndromes in sweet cherry and in other Prunus species [2,3,22]. Regarding the isolates analyzed in the present study, no clear conclusions can be drawn concerning their pathogenicity because as is very frequently the case the trees hosting them were co-infected with several viruses including in some cases different LChV1 genotypes. However, the LChV1 C118-iso13 and P8-42 isolates identified here show close phylogenetic relationships with the V2356 isolate which was strongly suggested to cause the Shirofugen stunt disease (SSD) [3], whereas the C118-iso15 variant grouped along with isolate ITMAR which was suggested to be involved in the Kwanzan stunting syndrome [2].

Supplementary Materials: The following are available online at http:/ /www.mdpi.com/1999-4915/10/7/385/s1, RT-PCR/RFLPs based analysis in samples C118 and P8. Figure S1: Maximum likelihood phylogenetic trees inferred from the partial (a) RdRp, (b) HSP70h and (c) CP nucleotide sequences, Table S1: Primers used to complete the full-length genomic sequence of the Kyoto-2 and G15 3 isolates, Table S2: Identity scores in nt and aminoacids among all full genome LChV1 isolates.

Author Contributions: V.I.M., A.O., A.M., T.C. conceived and designed the experiments; A.K., L.L., A.M., C.F., L.S.-D., A.B.R.-G. performed the experiments; A.K., L.L., S.T., T.C., A.O., A.B.R.-G. analyzed the data; A.K., V.I.M., T.C. wrote the paper; N.K., T.C., A.O. revised the paper. All authors discussed the results and contributed to the final manuscript.

Funding: Partial Research work and costs to publish in open access were supported by funds from VirFree. This project has received funding from the European Union's Horizon 2020 research and innovation programme under the Marie Skłodowska-Curie grant agreement No 734736. This publication reflects only the authors' view. The Agency is not responsible for any use that may be made of the information it contains. This research has also been co-financed by the European Union (European Social Fund-ESF) and Greek National Funds through the Operational Program "Education and Lifelong Learning" of the National Strategic Reference Framework (NSRF) - Research Funding Program: Heracleitus II. Investing in knowledge society through the European Social Fund.

Acknowledgments: The authors would like to acknowledge the contribution of the COST Action FA1407-DIVAS.

Conflicts of Interest: The authors declare no conflict of interest. The founding sponsors had no role in the design of the study; in the collection, analyses, or interpretation of data; in the writing of the manuscript, and in the decision to publish the results.

\section{References}

1. Martelli, G.P.; AbouGhanem-Sabanadzovic, N.; Agranovsky, A.A.; Al Rwahnih, M.; Dolja, V.V.; Dovas, C.I.; Fuchs, M.; Gugerli, P.; Hu, J.S.; Jelkmann, W.; et al. Taxonomic revision of the family Closteroviridae with special reference to the grapevine leafroll-associated members of the genus Ampelovirus and the putative species unassigned to the family. J. Plant Pathol. 2012, 94, 7-19.

2. Matic, S.; Minafra, A.; Sanchez-Navarro, J.A.; Pallas, V.; Myrta, A.; Martelli, G.P. 'Kwanzan Stunting' syndrome: Detection and molecular characterization of an Italian isolate of Little cherry virus 1 . Virus Res. 2009, 143, 61-67. [CrossRef] [PubMed]

3. Candresse, T.; Marais, A.; Faure, C.; Gentit, P. Association of Little cherry virus 1(LChV1) with the Shirofugen stunt disease and characterization of the genome of a divergent LChV1 isolate. Phytopathology 2013, 103, 293-298. [CrossRef] [PubMed]

4. Jelkmann, W.; Fechtner, B.; Agranovsky, A.A. Complete genome structure and phylogenetic analysis of Little cherry virus, a mealybug transmissible closterovirus. J. Gener. Virol. 1997, 78, 2067-2071. [CrossRef] [PubMed]

5. Lim, S.; Igori, D.; Yoo, R.H.; Zhao, F.; Cho, I.S.; Choi, G.S.; Lim, H.S.; Lee, S.H.; Moon, J.S. Genomic detection and characterization of a Korean isolate of Little cherry virus 1 sampled from a peach tree. Virus Genes 2015, 51, 260-266. [CrossRef] [PubMed]

6. Wang, J.; Zhu, D.; Tan, Y.; Zong, X.; Wei, H.; Hammond, R.W.; Liu, Q. Complete nucleotide sequence of Little cherry virus 1 (LChV1) infecting sweet cherry in China. Arch. Virol. 2016, 161, 749-753. [CrossRef] [PubMed]

7. Ruiz-García, A.B.; Martinez, C.; Santiago, R.; Garcia, M.T.; de Prado, N.; Olmos, A. First report of Little cherry virus 1 (LChV1) in sweet cherry in Spain. Plant Dis. 2016, 100, 2340. [CrossRef] 
8. Katsiani, A.T.; Maliogka, V.I.; Amoutzias, G.D.; Efthimiou, K.E.; Katis, N.I. Insights into the genetic diversity and evolution of Little cherry virus 1. Plant Pathol. 2015, 64, 817-824. [CrossRef]

9. Adams, I.P.; Glover, R.H.; Monger, W.A.; Mumford, R.; Jackeviciene, E.; Navalinskiene, M.; Samuitiene, M.; Boonham, N. Next-generation sequencing and metagenomic analysis: A universal diagnostic tool in plant virology. Mol. Plant Pathol. 2009, 10, 537-545. [CrossRef] [PubMed]

10. Kreuze, J.F.; Perez, A.; Untiveros, M.; Quispe, D.; Fuentes, S.; Barker, I.; Simon, R. Complete viral genome sequence and discovery of novel viruses by deep sequencing of small RNAs: A generic method for diagnosis, discovery and sequencing of viruses. Virology 2009, 388, 1-7. [CrossRef] [PubMed]

11. Hadidi, A.; Flores, R.; Candresse, T.; Barba, M. Next-Generation Sequencing and Genome Editing in Plant Virology. Front. Microbiol. 2016, 7, Article 1325. [CrossRef]

12. Bag, S.; Al Rwahnih, M.; Li, A.; Gonzalez, A.; Rowhani, A.; Uyemoto, J.K.; Sudarshana, M.R. Detection of a new luteovirus in imported nectarine trees: A case study to propose adoption of metagenomics in post-entry quarantine. Phytopathology 2015, 105, 840-846. [CrossRef] [PubMed]

13. Villamor, D.E.V.; Mekuria, T.A.; Eastwell, K.C. High-Throughput sequencing identifies novel viruses in nectarine: Insights to the etiology of stem-pitting disease. Phytopathology 2016, 106, 519-527. [CrossRef] [PubMed]

14. Kinoti, W.M.; Constable, F.E.; Nancarrow, N.; Plummer, K.M.; Rodoni, B. Analysis of intra-host genetic diversity of Prunus necrotic ringspot virus (PNRSV) using amplicon next generation sequencing. PLoS ONE 2017. [CrossRef] [PubMed]

15. Marais, A.; Faure, C.; Couture, C.; Bergey, B.; Gentit, P.; Candresse, T. Characterization by deep sequencing of divergent plum bark necrosis stem pitting associated virus isolates and development of a broad spectrum PBNSPaV-specific detection assay. Phytopathology 2014, 104, 660-666. [CrossRef] [PubMed]

16. Nicholas, K.B.; Nicholas, H.B., Jr.; Deerfield, D.W., II. GeneDoc: Analysis and Visualization of Genetic Variation. Embnew. News 1997, 4, 14.

17. Edgar, R.C. MUSCLE: Multiple sequence alignment with high accuracy and high throughput. Nucleic Acids Res. 2004, 32, 1792-1797. [CrossRef] [PubMed]

18. Tamura, K.; Peterson, D.; Peterson, N.; Stecher, G.; Nei, M.; Kumar, S. MEGA5: Molecular evolutionary genetics analysis using maximum likelihood, evolutionary distance and maximum parsimony methods. Mol. Biol. Evol. 2011, 28, 2731-2739. [CrossRef] [PubMed]

19. Martin, D.P.; Murrell, B.; Golden, M.; Khoosal, A.; Muhire, B. RDP4: Detection and analysis of recombination patterns in virus genomes. Virus Evol. 2015, 1, vev003. [CrossRef] [PubMed]

20. Katoh, K.; Standley, D.M. MAFFT multiple sequence alignment software version 7: Improvements in performance and usability. Mol. Biol. Evol. 2013, 30, 772-780. [CrossRef] [PubMed]

21. Rott, M.E.; Jelkmann, W. Detection and partial characterization of a second closterovirus associated with little cherry disease, Little cherry virus-2. Phytopathology 2001, 91, 261-267. [CrossRef] [PubMed]

22. Bajet, N.B.; Unruh, T.R.; Druffel, K.L.; Eastwell, K.C. Occurrence of two Little cherry viruses in sweet cherry in Washington State. Plant Dis. 2008, 92, 234-238. [CrossRef]

23. Zong, X.; Wang, W.; Wei, H.; Wang, J.; Yan, X.; Hammond, R.W.; Liu, Q. Incidence of sweet cherry viruses in Shandong province, China and a case study on multiple infection with five viruses. J. Plant Pathol. 2015, 97, 61-68.

24. Glasa, M.; Benediková, D.; Predajňa, L. First report of Little cherry virus-1 in Slovakia. J. Plant Pathol. 2015, 97, 541-551.

25. Katsiani, A.T.; Pappi, P.; Olmos, A.; Efthimiou, K.E.; Maliogka, V.I.; Katis, N.I. Development of a Real-Time RT-PCR for the universal detection of LChV1 and study of the seasonal fluctuation of the viral titer in sweet cherry cultivars. Plant Dis. 2018, 102, 899-904. [CrossRef]

26. Smith, J.M. Analyzing the mosaic structure of genes. J. Mol. Evol. 1992, 34, 126-129. [CrossRef] [PubMed]

27. Padidam, M.; Sawyer, S.; Fauquet, C.M. Possible emergence of new geminiviruses by frequent recombination. Virology 1999, 265, 218-225. [CrossRef] [PubMed]

28. Posada, D.; Crandall, K.A. Evaluation of methods for detecting recombination from DNA sequences: Computer simulations. Proc. Natl. Acad. Sci. USA 2001, 98, 13757-13762. [CrossRef] [PubMed]

29. Martin, D.P.; Posada, D.; Crandall, K.A.; Williamson, C. A modified bootscan algorithm for automated identification of recombinant sequences and recombination breakpoints. AIDS Res. Hum. Retrovir. 2005, 21, 98-102. [CrossRef] [PubMed] 
30. Boni, M.F.; Posada, D.; Feldman, M.W. An exact nonparametric method for inferring mosaic structure in sequence triplets. Genetics 2007, 176, 1035-1047. [CrossRef] [PubMed]

31. Roossinck, M.J. Deep sequencing for discovery and evolutionary analysis of plant viruses. Virus Res. 2017, 239, 82-86. [CrossRef] [PubMed]

32. Martelli, G.P.; Agranovsky, A.A.; Bar-Joseph, M.; Boscia, D.; Candresse, T.; Coutts, R.H.A.; Dolja, V.V.; Hu, J.S.; Jelkmann, W.; Karasev, A.V.; et al. Family ClosteroviridaeIn: Virus Taxonomy-Ninth Report of the International Committee on Taxonomy of Viruses; King, A.M.Q., Adams, M.J., Carstens, E.B., Lefkowitz, E.J., Eds.; Academic Press: San Diego, CA, USA, 2011; pp. 987-1001.

33. Prosser, S.W.; Goszczynski, D.E.; Meng, B. Molecular analysis of double-stranded RNAs reveals complex infection of grapevines with multiple viruses. Virus Res. 2007, 124, 151-159. [CrossRef] [PubMed]

34. Mandahar, C.L. Positive Sense Viral RNA. In Multiplication of RNA Plant Viruses; Springer: Dordrecht, The Netherlands, 2006; pp. 29-63.

35. Tian, T.; Rubio, L.; Yeh, H.H.; Crawford, B.; Falk, B.W. Lettuce infectious yellows virus: In Vitro acquisition analysis using partially purified virions and the whitefly, Bemisiatabaci. J. Gener. Virol. 1999, 80, 1111-1117. [CrossRef] [PubMed]

36. Satyanarayana, T.; Gowda, S.; Mawassi, M.; Albiach-Martí, M.R.; Ayllón, M.A.; Robertson, C.; Garnsey, S.M.; Dawson, W.O. Closterovirus encoded HSP70 homolog and p61 in addition to both coat proteins function in efficient virion assembly. Virology 2000, 278, 253-265. [CrossRef] [PubMed]

37. Alzhanova, D.V.; Napuli, A.; Creamer, R.; Dolja, V.V. Cell-to-cell movement and assembly of a plant closterovirus: Roles for the capsid proteins and Hsp70 homolog. EMBO J. 2001, 20, 6997-7007. [CrossRef] [PubMed]

38. Mawassi, M.; Mietkiewska, E.; Gofman, R.; Yang, G.; Bar-Joseph, M. Unusual sequence relationships between two isolates of Citrus tristeza virus. J. Gener. Virol. 1996, 77, 2359-2364. [CrossRef] [PubMed]

39. Reed, J.C.; Kasschau, K.D.; Prokhnevsky, A.I.; Gopinath, K.; Pogue, G.P.; Carrington, J.C.; Dolja, V.V. Suppressor of RNA silencing encoded by Beet yellows virus. Virology 2003, 306, 203-209. [CrossRef]

40. Lu, R.; Folimonov, A.S.; Shintaku, M.; Li, W.X.; Falk, B.W.; Dawson, W.O.; Ding, S.W. Three distinct suppressors of RNA silencing encoded by a 20-kb viral RNA genome. Proc. Natl. Acad. Sci. USA 2004, 101, 15742-15747. [CrossRef] [PubMed]

41. Katsiani, A.; Katsarou, K.; Kalantidis, K.; Katis, N.I.; Maliogka, V.I. Identification of an RNA silencing suppressor encoded by the genome of Little Cherry Virus 1. In Proceedings of the 24st International Conference on Virus and other Graft Transmissible Diseases of Fruit Crops, Thessaloniki, Greece, 5-9 June 2017; p. 113.

(C) 2018 by the authors. Licensee MDPI, Basel, Switzerland. This article is an open access article distributed under the terms and conditions of the Creative Commons Attribution (CC BY) license (http://creativecommons.org/licenses/by/4.0/). 